\title{
Bureaucratic Knowledge of The Quality of Tourism Service In Lake Toba Parapat North Sumatera
}

\author{
Erika Revida \\ Public Administration Departement \\ University of Sumatera Utara \\ Medan, Indonesia \\ erikarevida@yahoo.com
}

\author{
Sukarman Purba \\ Education Management Departement \\ Stated University of Medan \\ Medan, Indonesia \\ arman_prb@yahoo.com
}

\begin{abstract}
The purpose of this research was to determine and analyze Bureaucratic Knowledge of The Quality of Tourism Service In Lake Toba Parapat North Sumatera.

Method of this research used by descriptive qualitative research method. Respondents were 30 bureaucratics in Girsang Sipangan Bolon District Lake Toba Parapat North Sumatera. Data collection technique was research instrument (questionnaire), interview and observation. The Bureaucratic knowledge was measured by assigning scores/grades on 27 questions. For the correct answers rated 1, and false answers rated 0. Data analysis techniques used by data organization, reduction and interpretations.
\end{abstract}

The result showed that bureaucratic knowledge of the quality of tourism service in Lake Toba Parapat North Sumatera were good. But the high knowledge alone is not enough. It needs to implement with a high willingness and commitment for bureaucratic and also all stakeholders include businesses, society and government.

Keywords-Bureaucratic Knowledge, Quality of Tourism Services, and Tourism Visits.

\section{INTRODUCTION}

The essence of regional autonomy is to enhance the quality of public services in various sectors including the quality of bureaucratic tourism service1). But, the major problems in all countries now especially Indonesia is the limit of quality of bureaucratic tourism service.

In some countries today especially Indonesia, the need to enjoy tourism not only owned by the upper class (the haves), but also the middle and lower class (the havenot). Therefore bureucratic in Indonesia especially in Lake Toba North Sumatera now on, must be able to see these opportunities by giving the quality of tourism service best.

Salah (2003) states that tourism is one of industries that able to produce rapid economic growth in employment, improve the living standards, as well as stimulate the productivity of other sectors.2)

Additionally, Spillane (2002) explains that the role of tourism in the development country cored three aspects, namely the economic aspect, social aspect create jobs, and culture aspect can introduce culture to tourists 3 )

On the other hand, tourism sector is considered as one of the breakthroughs to increase locally-generated revenue (PAD) and society incomes. In addition, Tourism could be one of the means to promote arts and culture sector, adhesives nation and create new jobs.

Bureaucratic are one of an actor of regional autonomy and obliged to implement the quality of public services. Since regional autonomy the issue of the quality of public services, that is always an interested things to be studied and discussed. This is due that, the success of the implementation of regional autonomy depends on degree of the public services quality especially the quality of bureaucratic tourism services.

But in reality, largely bureaucrats in Indonesia especially in Lake Toba Parapat North Sumatera apparently still not aware of the importance of quality of tourism service. It seems that from year to year the tourist visit became decrease. That was the reason why the research done by taking the tittle " Bureaucratic Knowledge of The Quality of Tourism Service In Lake Toba Parapat North Sumatera".

\section{RESEARCH METHOD}

The method used in this research was descriptive qualitative research method. Respondents are 30 bureaucrats in the District Girsang Sipangan Bolon Lake Toba Parapat North Sumatera as many as 30 employee government there (total sampling). Bureaucratic Knowledge was measured by assigning scores / grades on 26 questions with a score for correct answers were 1 , and false answers by 0 . Variable knowledge have the highest score 26 and the lowest value of 0 . Based on knowledge variable scores then categorized into 3 categories, that was :

- Good when respondents answer correctly $>75 \%$ of the total score obtained

- Enough when respondents answer right $45-74 \%$ of the total score obtained

- less when respondents correctly $<45 \%$ of the total skori obtained. 


\section{RESULT AND DISCUSSIONS}

Knowledge is the result of human knows obtained through sight or sensing to a particular object. Notoatmodjo (2003), stated that knowledge is the result out of a man who simply answering the question "What". Knowledge is the result of idea, and this occurred after people perform sensing on a specific object. Sensing, smell, taste, and touch4). According to the Kamus Umum Bahasa Indonesia (2005) is Knowledge can be interpreted as something you know, or that everything is known. Thus, knowledge is the beginning of a person's attitude and actions towards something5).

Zeithaml, et al. (1990)6) stated that Quality of service measured by five dimensions, namely Tangible, Reliability, Responsiviness, Assurance, and Empathy. Each dimension has the following indicators:

1) Tangible, consist of indicators : Appearance officer/apparatus in customer service, comfort of doing service, ease in the service process, discipline giving services, ease of access to customers in application of the service, and the use of tools in service,

2) Reliability, consist of indicators: Accuracy officers in serving customers, have a clear service standards, ability to use tools in the service process, and expertise of officers using the tools in the service process.

3) Responsiveness, consist of indicators : Respond to customer/applicant who wants to get the service, bureaucratic perform giving service quickly, bureaucratic service properly, bureaucratic service carefully, bureaucratic service at the right time, and all customer complaints responded to.

4) Assurance, consist of indicators: bureaucratic provide guarantees on time in service, bureaucratic guarantee the cost of the service, concierge, guarantees of legality in service, and the clerk gave assurance in service costs.

5) Empathy, consist of indicators: Putting the interests of the society, serve with a friendly attitude, bureaucratic serve with politeness, bureaucratic serve with no discrimination, and bureaucratic serve and appreciate every customer.

The following table was the results of the research instruments were submitted to 30 respondents bureaucrat in the district of Girsang Sipangan Bolon Lake Toba Parapat North Sumatera related to bureaucratic knowledge about the Quality of Tourism Services in Lake Toba Parapat North Sumatera.

Furthermore Bureaucratic Knowledge of the Quality of Tourism Services Parapat Lake Toba in North Sumatra took by instrument on 27 items of questions. The highest score was 27 and the lowest score was 0 as seen above.
Table.1. Bureaucratic Knowledge About The Quality of Tourism Services In Lake Toba Parapat North Sumatera, 2016.

\begin{tabular}{|c|c|c|c|}
\hline \multirow[t]{2}{*}{ No } & \multirow[t]{2}{*}{ Questions } & \multicolumn{2}{|c|}{$\begin{array}{l}\text { Respondent } \\
\text { answers }\end{array}$} \\
\hline & & Yes & No \\
\hline 1 & $\begin{array}{l}\text { Do you know defenition of quality of } \\
\text { tourism services? }\end{array}$ & $\begin{array}{c}25 \\
83,33 \%\end{array}$ & $\begin{array}{c}5 \\
16,67 \%\end{array}$ \\
\hline 2 & $\begin{array}{l}\text { Do you know the purpose of quality of } \\
\text { tourism services? }\end{array}$ & $\begin{array}{c}22 \\
73,33 \%\end{array}$ & $\begin{array}{c}8 \\
26,67 \%\end{array}$ \\
\hline 3 & $\begin{array}{l}\text { Do you know that the quality of tourism } \\
\text { services when the tourist sites clean from } \\
\text { garbage, sewage and others? }\end{array}$ & $\begin{array}{c}26 \\
86,67 \%\end{array}$ & $\begin{array}{c}4 \\
13,33 \%\end{array}$ \\
\hline 4 & $\begin{array}{l}\text { Do you know that the quality of tourism } \\
\text { services when there is an available and } \\
\text { adequate worship (mosque/mosques, } \\
\text { churches, other places of worship)? }\end{array}$ & $\begin{array}{c}20 \\
66,67 \%\end{array}$ & $\begin{array}{c}10 \\
33,33 \%\end{array}$ \\
\hline 5 & $\begin{array}{l}\text { Do you know that quality of tourism } \\
\text { services when there is an available safe } \\
\text { and comfortable park? }\end{array}$ & $\begin{array}{c}25 \\
83,33 \%\end{array}$ & $\begin{array}{c}5 \\
16,67 \%\end{array}$ \\
\hline 6 & $\begin{array}{l}\text { Do you know that the quality of tourism } \\
\text { services when there were available safe } \\
\text { and comfortable road/ infrastructure? }\end{array}$ & $\begin{array}{c}24 \\
80 \%\end{array}$ & $\begin{array}{c}6 \\
20 \%\end{array}$ \\
\hline 7 & $\begin{array}{l}\text { Do you know that the quality of tourism } \\
\text { services when there was an adequate } \\
\text { bureaucratic performance? }\end{array}$ & $\begin{array}{c}20 \\
66,67 \%\end{array}$ & $\begin{array}{c}10 \\
33,33 \%\end{array}$ \\
\hline 8 & $\begin{array}{l}\text { Do you know that the quality of tourism } \\
\text { services when bureaucratic have an } \\
\text { important skills serving tourists? }\end{array}$ & $\begin{array}{c}28 \\
93,33 \%\end{array}$ & $\begin{array}{c}2 \\
6,67 \%\end{array}$ \\
\hline 9 & $\begin{array}{l}\text { Do you know that the quality of tourism } \\
\text { services when bureaucrats provide tourism } \\
\text { services right? }\end{array}$ & $\begin{array}{c}21 \\
70 \%\end{array}$ & $\begin{array}{c}9 \\
30 \%\end{array}$ \\
\hline 10 & $\begin{array}{l}\text { Do you know that the quality of tourism } \\
\text { services when bureaucrats giving service } \\
\text { accordance with regulations? }\end{array}$ & $\begin{array}{c}25 \\
83,33 \%\end{array}$ & $\begin{array}{c}5 \\
16,67 \%\end{array}$ \\
\hline 11 & $\begin{array}{l}\text { Do you know that the quality of tourism } \\
\text { service when bureaucrats provide a fair } \\
\text { services to tourists? }\end{array}$ & $\begin{array}{c}28 \\
93,33 \%\end{array}$ & $\begin{array}{c}2 \\
6,67 \%\end{array}$ \\
\hline 12 & $\begin{array}{l}\text { Do you know that the quality of tourism } \\
\text { services when bureaucrats provide } \\
\text { satisfactory services? }\end{array}$ & $\begin{array}{c}26 \\
86,67 \%\end{array}$ & $\begin{array}{c}4 \\
86,67 \%\end{array}$ \\
\hline 13 & $\begin{array}{l}\text { Do you know that the quality of tourism } \\
\text { services when bureaucrats provide } \\
\text { responsive services? }\end{array}$ & $\begin{array}{c}23 \\
76,67 \%\end{array}$ & $\begin{array}{c}7 \\
23,33 \%\end{array}$ \\
\hline 14 & $\begin{array}{l}\text { Do you know that the quality of tourism } \\
\text { services when bureaucrats provide clear } \\
\text { information both directly and in writing } \\
\text { like banners, leaflets, web internet or other } \\
\text { media? }\end{array}$ & $\begin{array}{c}24 \\
80 \%\end{array}$ & $\begin{array}{c}6 \\
20 \%\end{array}$ \\
\hline 15 & $\begin{array}{l}\text { Do you know that the quality of tourism } \\
\text { services when bureaucrats Does the father } \\
\text { / mother / Br / i know that the quality of } \\
\text { tourism services when bureaucrats provide } \\
\text { tourism services that quickly? }\end{array}$ & $\begin{array}{c}26 \\
86,67 \%\end{array}$ & $\begin{array}{c}4 \\
86,67 \%\end{array}$ \\
\hline 16 & $\begin{array}{l}\text { Do you know that the quality of tourism } \\
\text { services when bureaucrats Does the father } \\
\text { / mother / Br / i know that the quality of } \\
\text { tourism services if bureaucrats can solve } \\
\text { the problem quickly? }\end{array}$ & $\begin{array}{c}25 \\
83,33 \%\end{array}$ & $\begin{array}{c}5 \\
83,33 \%\end{array}$ \\
\hline 17 & $\begin{array}{l}\text { Do you know that the quality of tourism } \\
\text { services when bureaucrats provide } \\
\text { proactive services? }\end{array}$ & $\begin{array}{c}22 \\
73,33 \%\end{array}$ & $\begin{array}{c}8 \\
26,67 \%\end{array}$ \\
\hline 18 & $\begin{array}{l}\text { Do you know that the quality of tourism } \\
\text { services when bureaucrats provide polite } \\
\text { and friendly services? }\end{array}$ & $\begin{array}{c}26 \\
86,67 \%\end{array}$ & $\begin{array}{c}4 \\
86,67 \%\end{array}$ \\
\hline 19 & $\begin{array}{l}\text { Do you know that the quality of tourism } \\
\text { services when bureaucrats provide } \\
\text { guaranteed services? }\end{array}$ & $\begin{array}{c}22 \\
73,33 \%\end{array}$ & $\begin{array}{c}8 \\
26,67 \%\end{array}$ \\
\hline
\end{tabular}


Table 1, cont.

\begin{tabular}{|c|c|c|c|}
\hline 20 & $\begin{array}{l}\text { Do you know that the quality of tourism } \\
\text { services when bureaucrats provides clear } \\
\text { informations? }\end{array}$ & $\begin{array}{c}28 \\
26,67 \%\end{array}$ & $\begin{array}{c}2 \\
6,67 \%\end{array}$ \\
\hline 21 & $\begin{array}{l}\text { Do you know that the quality of tourism } \\
\text { services when bureaucrats provide } \\
\text { Standard Operating Procedure (SOP) } \\
\text { tourism? }\end{array}$ & $\begin{array}{c}20 \\
66,67 \%\end{array}$ & $\begin{array}{c}10 \\
33,33 \%\end{array}$ \\
\hline 22 & $\begin{array}{l}\text { Do you know that the quality of tourism } \\
\text { services when bureaucrats provide The } \\
\text { Minimum Service Standards (SPM) } \\
\text { tourism? }\end{array}$ & $\begin{array}{c}21 \\
70 \%\end{array}$ & $\begin{array}{c}9 \\
30 \%\end{array}$ \\
\hline 23 & $\begin{array}{l}\text { Do you know that the quality of tourism } \\
\text { services when bureaucrats provide sincere } \\
\text { services? }\end{array}$ & $\begin{array}{c}20 \\
66,67 \%\end{array}$ & $\begin{array}{c}10 \\
33,33 \%\end{array}$ \\
\hline 24 & $\begin{array}{l}\text { Do you know that the quality of tourism } \\
\text { services when bureaucrats provides } \\
\text { specific services for tourists? }\end{array}$ & $\begin{array}{c}16 \\
53,33 \%\end{array}$ & $\begin{array}{c}14 \\
46,67 \%\end{array}$ \\
\hline 25 & $\begin{array}{l}\text { Do you know that the quality of tourism } \\
\text { services when bureaucrats have an } \\
\text { empathy services? }\end{array}$ & $\begin{array}{c}17 \\
56,67\end{array}$ & $\begin{array}{c}13 \\
43,33 \%\end{array}$ \\
\hline 26 & $\begin{array}{l}\text { Do you know that the quality of tourism } \\
\text { services when bureaucrats have broad } \\
\text { knowledge of tourism? }\end{array}$ & $\begin{array}{c}20 \\
66,67 \%\end{array}$ & $\begin{array}{c}10 \\
33,33 \%\end{array}$ \\
\hline 27 & $\begin{array}{l}\text { Do you know that the quality of tourism } \\
\text { services when bureaucrats ease } \\
\text { communicating with tourists? }\end{array}$ & $\begin{array}{c}21 \\
70 \%\end{array}$ & $\begin{array}{c}9 \\
30 \%\end{array}$ \\
\hline
\end{tabular}

Resource : Result of Research, 2016.

Based on bureaucratic knowledge of the Quality of Tourism Services in Lake Toba Parapat North Sumatra, then categorized into 3 (three) categories, namely :

- Good when respondents answer correctly> $75 \%$ of the total score obtained

- Enough when respondents answer right $45-74 \%$ of the total score obtained

- Less when respondents correctly $<45 \%$ of the total skori obtained.

Table 2. Category of Bureaucratic Knowledge of the Quality of Tourism Services In Lake Toba Parapat North Sumatera, 2016.

\begin{tabular}{|c|c|c|c|c|}
\hline No & Skor & Kategori & $\mathrm{F}$ & $\%$ \\
\hline 1 & $19-27$ & Good & 23 & 76,67 \\
\hline 2 & $10-18$ & Enough & 4 & 13,33 \\
\hline 3 & $0-9$ & Less & 3 & 10,00 \\
\hline \multicolumn{3}{|c|}{ Total } & 30 & 100,00 \\
\hline
\end{tabular}

Based on the table 2, it appeared that there were 23 people (76.67\%) of respondents bureaucratic had a good knowledge of the quality of tourism services, and there were 4 people $(13.33 \%)$ of respondents bureaucrats had enough knowledge on the Quality Tourism Services, and there were 3 people
(10\%) of respondents bureaucratic had less knowledge of the quality of tourism services. This research suggest that the real and good knowledge of bureaucrats on the Quality Tourism Services not enuogh yet. It needs to be accompanied by good practices anyway. It means that, to improve the quality of tourism services, bureaucrats not only had a good knowledge only but also need a high commitment and willingness to implement it.

In addition, a good knowledge (cognitive) tourism service quality will enrich a positive attitude towards the quality of tourism services and a good attitude (affective) of tourism services quality will influence the real act (psychomotoric) of tourism service quality anyway. Therefore, to maintanance the bureaucratic knowledge of tourism service quality in Lake Toba Parapat North Sumatera, it needs communication, information, education about tourism service quality continously with a high commitment and willingness of bureaucratic.

\section{CONCLUSIONS AND RECOMMENDATIONS}

Based on the research result, the conclusions of this research resumed that bureaucratic knowledge of quality of tourism service in Lake Toba Parapat North Sumatera was good. This was because they already getting the information about the advantages of tourism Lake Toba Parapat North Sumatera.

Therefore, recommendations of this research first, suggest that it is good to communicate and socialization about tourism to all of bureaucratic in Lake Toba Parapat North Sumatera intensively and continuously. The second, suggest that good knowledge of bureaucratic of tourism service quality not enough yet, it needs to implement by a high willingness and commitment of all of bureaucratic, stakeholders and society.

\section{References}

[1] Undang-undang Nomor 23 Tahun 2014 tentang Pemerintahan Daerah. Jakarta : Sekretariat Negara.

[2] Salah, Wahab. 2003. Manajemen Kepariwisataan, PT. Pradnya Paramita, Jakarta

[3] Spillane, James J. 2002. Ekonomi Pariwisata Sejarah dan Prosepeknya. Yogyakarta: Kanisius.

[4] Notoatmodjo Seskidjo. 2003. Ilmu Kesehatan Masyarakat : Prinsipprinsip Dasar. Jakarta : PT. Rineka Cipta,

[5] Pusat Pembinaan dan Pengembangan Bahasa. 2005. Kamus Umum Bahasa Indonesia. 2005. Jakarta : Balai Pustaka.

[6] Zeithaml, Valerie A Parasuraman A dan Leonard L.Berry. 1990. Delivery Quality Service, Balancing Customer Perceptions And Expectation. New York: The Free Press 